\title{
Odpowiedzialność penalna za ucieczkę osoby prawnie pozbawionej wolności w prawie rzymskim i prawie starożytnych Aten
}

Pozbawienie wolności fizycznej (tzw. lokomocyjnej), czyli swobody zmiany miejsca przebywania wedle własnej woli, jest jednym z najbardziej dolegliwych środków stosowanych wobec sprawców przestępstw. Prowadzi do oderwania więźnia od środowiska, w którym przebywał (krąg rodziny, przyjaciół, współpracowników i innych znajomych osób), „wtłacza” w nową rzeczywistość izolacji penitencjarnej, w której musi się on podporządkować pewnym zasadom postępowania, uniemożliwia lub znacznie utrudnia realizowanie planów życiowych itp. Nic dziwnego, że osoby pozbawione wolności decydują się na ucieczkę z miejsca uwięzienia. Są też osoby, które taką ucieczkę w różny sposób ułatwiają. W obowiązującym w Polsce prawie takie zachowania penalizowane są zgodnie z art. 242 i 243 k.k. ${ }^{1}$ Ponadto ucieczka może pociągać odpowiedzialność dyscyplinarną osoby pozbawionej wolności lub osoby, która jej pomagała (np. funkcjonariusza Służby Więziennej czy Policji).

Dążenie do odzyskania wolności jest dla człowieka naturalne, toteż ucieczki więźniów zdarzały się od czasów starożytnych. W niniejszym artykule przybliżę więc regulacje o charakterze penalnym obowiązujące w antycznym Rzymie i Ate-

${ }^{1}$ Ustawa z dnia 6 czerwca 1997 r. - Kodeks karny (t.j. Dz. U. 2019, poz. 1952 ze zm.). Zgodnie $\mathrm{z}$ art. $242 \S 1$ k.k. kto uwalnia się sam, będąc pozbawionym wolności na podstawie orzeczenia sądu lub prawnego nakazu wydanego przez inny organ państwowy, podlega grzywnie, karze ograniczenia wolności albo pozbawienia wolności do lat 2. Jeżeli sprawca takiego czynu działa w porozumieniu z innymi osobami, używa przemocy lub grozi jej użyciem albo uszkadza miejsce zamknięcia, podlega karze pozbawienia wolności do lat 3 (art. $242 \S 4$ k.k.). Natomiast kto osobę pozbawioną wolności na podstawie orzeczenia sądu lub prawnego nakazu wydanego przez inny organ państwowy uwalnia lub ułatwia jej ucieczkę, podlega karze pozbawienia wolności do lat 3 (art. 243 k.k.). 
nach, a odnoszące się do ucieczek więźniów i czynów polegających na ułatwieniu ucieczek takich osób. Z uwagi na dostępność źródeł dokładniej opiszę rozwiązania przyjęte w prawie rzymskim, natomiast te dotyczące prawa starożytnych Aten tylko zasygnalizuję, aby zainspirować czytelników do pogłębionych analiz.

Jeśli chodzi o terminologię, to $\mathrm{w}$ artykule posługuję się pojęciem odpowiedzialności penalnej, a nie karnej. Odpowiedzialność penalna jest pojęciem szerszym i obejmuje wszystkie te przypadki, w których naruszenie prawa naraża daną osobę na dolegliwość w postaci kary. W kontekście ucieczek więźniów warto wskazać, że odpowiedzialnością penalną będzie nie tylko odpowiedzialność karna za popełnienie przestępstwa (z czym wiąże się możliwość wymierzenia kary kryminalnej), ale też odpowiedzialność dyscyplinarna (przewidująca za delikty/przekroczenia dyscyplinarne kary dyscyplinarne). W dzisiejszym prawie odróżnienie odpowiedzialności stricte karnej od dyscyplinarnej nie nastręcza trudności. W nauce rzymskiego prawa karnego unikano jednak generalizowania i tworzenia teoretycznych konstrukcji ${ }^{2}$. Uznałem więc za istotne, by w poniższych rozważaniach przedstawić regulacje dotyczące nakładania kar w związku z ucieczkami więźniów, niezależnie od tego, czy dziś uznalibyśmy daną dolegliwość za karę kryminalną, czy dyscyplinarną.

Pisząc o więźniach, mam na myśli osoby, które zostały zgodnie z prawem pozbawione wolności w związku z popełnionym przez nie (albo zarzucanym im) przestępstwem. Nie wikłając się w kwestie związane ze współczesną karnistyczną definicją przestępstwa, przyjmuję na potrzeby niniejszego artykułu, że chodzi o jakikolwiek czyn zabroniony pod groźbą kary. Pozbawieniem wolności będzie natomiast izolacja zastosowana na etapie przed skazaniem (pozbawienie wolności jako środek zapobiegawczy, mający zabezpieczyć prawidłowy przebieg postępowania w sprawie o przestępstwo) oraz po skazaniu (areszt stosowany po wydaniu wyroku, a przed wykonaniem kary, np. śmierci, bądź wykonanie kary izolacyjnej). Nie będę więc się zajmował problemem ucieczek osób pozbawionych wolności na innej podstawie.

\section{PRAWO RZYMSKIE}

W pierwszej kodyfikacji prawa rzymskiego, tj. w ustawie XII tablic, sporządzonej w $\mathrm{V}$ w. p.n.e., nie było przepisów dotyczących odzyskania wolności przez uwięzionego. Najwcześniejsze regulacje pochodzą z okresu pryncypatu. Ich źródłem są w dużej mierze reskrypty cesarza Hadriana panującego w latach 117-138 n.e.

${ }^{2}$ K. Amielańczyk, Teoretyczny model przestępstwa prawa publicznego (crimen publicum) autorstwa Claudiusa Saturninusa (D. 48,19,16) a wspótczesna nauka o przestęstwie karnym, „Annales Universitatis Mariae Curie-Skłodowska”, sectio G (Ius) 2019, nr 1, s. 19-20. 
Prawo rzymskie przewidywało odpowiedzialność penalną dla dwóch grup podmiotów: 1) osób, które uwolniły się same, będąc pozbawionymi wolności³ 2) osób, które dopuściły (nieumyślnie) do uwolnienia więźnia bądź (umyślnie) uwolniły go. Przed omówieniem tych uregulowań warto wskazać, jakie były podstawy pozbawienia wolności w starożytnym Rzymie 4

Pojęciem carcer określano pozbawienie wolności, które pełniło funkcję środka zapobiegawczego ${ }^{5}$. Był to więc, w dzisiejszej terminologii, areszt tymczasowy, poprzez który zapobiegano ucieczce oskarżonego podczas prowadzonego przeciw niemu postępowania, a także po wydaniu wyroku skazującego ${ }^{6}$. Jeśli chodzi o kary połączone z pozbawieniem wolności (custodia), to prawo rzymskie znało karę pracy przymusowej w kopalni (in metallum, opus metalli) ${ }^{7}$ oraz karę przymusowych robót publicznych (opus publicum) ${ }^{8}$. Kara pozbawienia wolności (vincula) była, przy-

${ }^{3}$ Ponoszenie odpowiedzialności za ucieczkę przez osoby pozbawione wolności nie jest oczywiste. O ile we współczesnej Polsce takie zachowanie podlega karze, o tyle w kręgu germańskiej kultury prawnej punktem ciężkości już od leges barbarorum z VI i VII w. była odpowiedzialność osób uwalniających więźnia bądź ułatwiających mu ucieczkę. Zob. P. Poniatowski, Przestępstwa uwolnienia osoby prawnie pozbawionej wolności (art. 242 i 243 k.k.), Warszawa 2019, s. 41 . Z kolei w prawie rzymskim ucieczka więźnia traktowana była jako zamach na władzę państwową, w związku z czym pociągała za sobą surową karę. Zob. M. Helm, Das Delikt der Gefangenenbefreiung, Berlin 2010, s. 30 oraz wypowiedź J. Makarewicza podczas posiedzenia sekcji prawa karnego Komisji Kodyfikacyjnej Rzeczypospolitej Polskiej 30.01.1923 r., Komisja Kodyfikacyjna Rzeczypospolitej Polskiej. Sekcja Prawa Karnego, t. II, Lwów 1925, s. 36.

${ }^{4} \mathrm{~K}$. Amielańczyk podkreśla, że analizując źródła prawa rzymskiego, nie zawsze można jednoznacznie ustalić, czy pozbawienie wolności było jedną z dostępnych kar, środkiem zapobiegawczym, czy też jednym i drugim. Zob. K. Amielańczyk, Rzymskie prawo karne w reskryptach cesarza Hadriana, Lublin 2006, s. 212. Takie same wnioski można wyciągnąć z lektury pracy O.F. Robinson, The Criminal Law of Ancient Rome, Baltimore 1995, s. 6. Zob. też T. Mommsen, Römisches Strafrecht, Leipzig 1899, s. 48-49, 299-300, 960-963.

${ }^{5}$ K. Amielańczyk, Rzymskie prawo karne..., s. 213. Należy zauważyć, że więzień przebywający w carcerze zakuwany był w kajdany, co miało utrudnić mu ucieczkę. Zob. K. Amielańczyk, Środki przeciwdziałania unikaniu odpowiedzialności karnej w prawie rzymskim okresu pryncypatu, „Czasopismo Prawno-Historyczne” 2007, t. LIX, z. 2, s. 50.

${ }^{6}$ A. Berger, Encyclopedic Dictionary of Roman Law, Philadelphia 1991, s. 381.

${ }^{7}$ Digesta Justyniańskie 48, 19, 8, 4: Est poena, quae adimat libertatem: huiusmodi ut puta, si quis in metallum vel in opus metalli damnetur. Różnica między skazaniem in metallum a in opus metalli dotyczyła rodzaju łańcuchów, w które zakuwano więźniów. W pierwszym przypadku używano cięższych łańcuchów, w drugim zaś lżejszych (Digesta 48, 19, 8, 6). Źródło tekstu Digestów: http://www.thelatinlibrary.com/justinian.html [dostęp: 27.01.2020]. Kara in metallum wykonywana była dożywotnio i stanowiła najsurowszą karę, zaraz po karze śmierci. Zob. A. Berger, Encyclopedic Dictionary..., s. 581. Była ona proxima morti poena - bliska karze śmierci (Digesta 48, 19, 28pr.).

${ }^{8}$ K. Amielańczyk, Rzymskie prawo karne..., s. 216 i 222. Kara robót publicznych obejmowała obowiązek budowy i odnawiania dróg, czyszczenia kanałów ściekowych, służenia w łaźniach publicznych, piekarniach, tkalniach (w przypadku kobiet) itp. Zob. A. Berger, Encyclopedic Dictionary..., s. 610 . 
najmniej w czasach Hadriana, stosowana w ograniczonym zakresie9. W niektórych wypadkach wymierzana była kara dożywotniego więzienia (perpetua vincula) ${ }^{10}$. Wiadomo też, że cesarz pozwalał wymierzać karę czasowego pozbawienia wolności (vincula temporaria) $\mathrm{w}$ przypadku niewolnikó $\mathrm{w}^{11}$.

Jeśli chodzi o samouwolonienie więźnia z aresztu, to w tytule trzecim księgi 48 Digestów - De custodia et exhibitione reorum (dotyczącym strzeżenia oskarżonego) - znajduje się przekaz Callistratusa ${ }^{12}$, zgodnie z którym jeśli osoby uwięzione w areszcie (carcer) zmówiły się w celu zerwania więzów i ucieczki, to powinny być ukarane niezależnie od przyczyny, dla której zostały aresztowane ${ }^{13}$. Nawet jeśli osoby takie zostały później uniewinnione od zarzucanego im czynu, w związku z którym zostały uwięzione, kara nie mogła ich ominąć. Prawo przewidywało też instytucję czynnego żalu, gdyż spiskowiec, który ujawnił zmowę, powinien być ukarany łagodniej. Za wskazany czyn groziła aresztantom prawdopodobnie kara śmierci ${ }^{14}$.

9 Trafnie zauważa K. Amielańczyk, że kara ta być może nie rozwinęła się z powodów czysto praktycznych (koszty związane z budową więzień i nadzorem nad nimi). Represja i cele wychowawcze mogły być realizowane przez inne kary (przymusowe prace publiczne, przymusowa praca w kopalni) i to z wymiernym pożytkiem dla skarbu państwa. Zob. K. Amielańczyk, Rzymskie prawo karne..., s. 222.

${ }^{10}$ Ibidem, s. 214.

${ }^{11}$ Ibidem, s. 215, 221-222. A. Berger (Encyclopedic Dictionary..., s. 765) podaje, że vincula, tj. pętanie kajdanami, stanowiło karę stosowaną wobec niewolników przez ich panów. Jednak kara ta miała w stosunku do niewolników specyficzny charakter. Osoby te były bowiem traktowane w prawie rzymskim jak rzeczy - rzeczy, których zakres korzystania z wolności osobistej był uzależniony od woli pana (właściciela). Już więc sam stan niewolnictwa powodował, że dana osoba była prawnie pozbawiona wolności fizycznej (lokomocyjnej). Stosowanie vincula stanowiło tedy odarcie niewolnika z resztek tej wolności, całkowicie uniemożliwiając mu zmianę miejsca przebywania.

${ }_{12}$ Digesta 48, 3, 13: In eos, qui, cum recepti essent in carcerem, conspiraverint, ut ruptis vinculis et effracto carcere evadant, amplius, quam causa ex qua recepti sunt reposcit, constituendum est quamvis innocentes inveniantur ex eo crimine, propter quod impacti sunt in carcere, tamen puniendi sunt: eos vero, qui conspirationem eorum detexerint, relevandos.

${ }_{13}$ Obowiązujący kodeks karny nie przewiduje takiego rodzaju przestępstwa. Trzeba jednak pamiętać, że art. $150 \S 3$ k.k. z 1932 r. (rozporządzenie Prezydenta Rzeczypospolitej z dnia 11 lipca 1932 r. - Kodeks karny, Dz. U. Nr 60, poz. 571 ze zm.) przewidywał karę dla tego, kto wchodzi $\mathrm{w}$ porozumienie $\mathrm{z}$ innymi uwięzionymi w celu uwolnienia się z zamknięcia według ułożonego planu i w przewidywaniu użycia przemocy, groźby lub uszkodzenia miejsca zamknięcia.

${ }_{14}$ Tak K. Amielańczyk, Środki przeciwdziałania..., s. 58. Już w okresie Republiki uciekinierzy byli karani śmiercią. Tytus Liwiusz opisał w swoim dziele $A b$ urbe condita (księga XXV, rozdział 7) przypadek z 212 r. p.n.e., kiedy to uwięzieni w sądzie zakładnicy z miasta Tarent uciekli pod osłoną nocy z pomocą swojego krajana Fileasa. Kiedy zaczęło świtać, wieść o ucieczce rozniosła się po mieście. Za zbiegami wysłano pościg. Zostali oni złapani w mieście Tarracina, przyprowadzeni na comitium (miejsce zgromadzeń ludowych w starożytnym Rzymie), wychłostani przy aprobacie ludności i ostatecznie zrzuceni ze skały. Zob. The History of Rome by Titus Livius, thum. G. Baker, t. III, New York 1823, s. 256. 
Zgodnie z przekazem Ulpiana ${ }^{15}$, który przytoczył reskrypt Marka Aureliusza i Lucjusza Werusa (sprawowali oni wspólne rządy w latach 161-169 n.e.), osoby uciekające $\mathrm{z}$ aresztu powinny być karane śmiercią. W tym samym miejscu powołany jest jurysta Saturninus, który wskazywał, że uwalniający się z aresztu, czy to wyłamujący drzwi, czy spiskujący z innymi aresztantami, powinien być karany śmiercią; jeśli jednak ucieczka nastąpiła na skutek niedbalstwa strażników, odpowiedzialność była łagodzona. W przypadku usiłowania ucieczki sprawca podlegał łagodniejszej karze ${ }^{16}$. Z przekazu Paulusa wiadomo, że żołnierz, który uwolnił się $\mathrm{z}$ aresztu, używając miecza, podlegał karze śmierci. Takiej samej karze podlegał żołnierz-strażnik, który uciekł (zdezerterował) razem z osobą, którą miał pilnować17. W księdze 49 Digestów, w rozdziale szesnastym, dotyczącym kwestii wojskowości (De re militari), znajduje się fragment dzieła jurysty Aemiliusa Macera ${ }^{18}$, który przywołał opinię innego prawnika, Arriusa Menandera, zgodnie z którą żołnierz przebywający pod strażą lub w areszcie nie powinien być w razie ucieczki traktowany jak dezerter, gdyż nie porzuca armii, a jedynie odzyskuje wolność, której go pozbawiono $^{19}$. W tym samym miejscu Macer przywołuje stwierdzenie Paulusa, że osoba, która wyłamuje się z aresztu, podlega karze śmierci, nawet jeśli wcześniej nie dopuściła się dezercji.

Jeśli chodzi o uwolnienie się osoby odbywającej już karę, to należy przywołać reskrypt cesarza Hadriana, znany z umieszczonego w tytule dziewięt-

${ }^{15}$ Digesta 47,18,1pr.: De his, qui carcere effracto evaserunt, sumendum supplicium divi fratres Aemilio Tironi rescripserunt. Saturninus etiam probat in eos, qui de carcere eruperunt sive effractis foribus sive conspiratione cum ceteris, qui in eadem custodia erant, capite puniendos: quod si per neglegentiam custodum evaserunt, levius puniendos. K. Amielańczyk zauważa, że regulacja ta dotyczyła zapewne przetrzymywanych w areszcie złodziei (idem, Środki przeciwdziałania..., s. 58). Jest to wysoce prawdopodobne, gdyż omawiany reskrypt przywołany został w księdze 47 Digestów w tytule De effractoribus et expilatoribus (O włamywaczach i rabusiach).

${ }^{16}$ Zob. zdanie Juliusa Clarusa przywołane w The Scottish Jurist, t. IV, Edinburgh 1832, s. 412.

${ }_{17}$ Sentecje Paulusa 5,31,5: Miles, qui ex carcere dato gladio erupit, poena capitis punitur. Eadem poena tenetur et qui cum eo quem custodiebat deseruit. Źródło tekstu: http://www.ancientrome.ru/ius/library/paul/paul5.htm [dostęp: 27.01.2020].

${ }_{18}$ Digesta 49, 16, 13, 5: Eius fugam, qui, cum sub custodia vel in carcere esset discesserit, in numero desertorum non computandam menander scripsit, quia custodiae refuga, non militiae desertor est. eum tamen, qui carcere effracto fugerit, etiamsi ante non deseruerit, capite puniendum Paulus scripsit.

19 Można sądzić, że wskazane rozróżnienie miało związek ze sposobem wykonania kary śmierci. Dezerterzy dopuszczali się zbrodni zdrady stanu, więc karani byli w sposób brutalny - stosowano ścięcie toporem poprzedzone chłostą albo biczowanie kijami (supplicium fustuarium). Zob. P. Kołodko, Chłosta jako kara w rzymskim wojskowym prawie karnym, „Studia Prawnoustrojowe” 2007, $\mathrm{nr}$ 7, s. 64. W stosunku do „zwykłych” uciekinierów-aresztanów (niebędących dezerterami) przeważnie nie stosowano kwalifikowanych rodzajów kary śmierci. Trzeba jednak dodać, że w okresie pokoju dezercja karana była łagodniej niż karą śmierci. Zob. Digesta 49, 16, 5, 1: Qui in pace deseruit, eques gradu pellendus est, pedes militiam mutat. in bello idem admissum capite puniendum est. 
nastym księgi 48 Digestów (De poenis - O karach) przekazu Callistratusa ${ }^{20}$, który w następujący sposób reguluje konsekwencje ucieczki: jeśli więzień skazany był na określony czas, powinien być ukarany bezterminowo (dożywotnio); jeśli więzień był skazany bezterminowo, powinien być ukarany pracą w kopalni ( $\mathrm{w}$ formie cięższej - in metallum); jeśli zaś był skazany na pracę w kopalni (in metallum), ucieczka jego pociągała karę śmierci ${ }^{21}$. Zdaniem K. Amielańczyka nie chodzi tu o terminową albo dożywotnią karę pozbawienia wolności, a o karę robót publicznych (opus publicum) ${ }^{22}$. W tym samym tytule księgi 48 Digestów znajduje się przekaz Ulpiana ${ }^{23}$, który opisuje różnice między skazaniem opus metalli a in metallum oraz stwierdza, że jeśli skazany na tę pierwszą karę uciekł, powinien być ukarany pracą in metallum, natomiast jeśli był skazany na drugą karę i uciekł, powinien być ukarany jeszcze surowiej (biorąc pod uwagę wcześniejsze uwagi, można sądzić, że chodzi o karę śmierci). Ulpian wskazuje również inne (niż opisane przez Callistratusa) możliwe konsekwencje uwolnienia się od kary robót publicznych (opus publicum $)^{24}$. Stwierdza on, że osoba skazana na tę karę, która uciekła, powinna być ukarana obowiązkiem wykonywania tej pracy w podwójnym wymiarze czasu, który pozostał jeszcze do odpracowania. Jeśli osoba taka była skazana na 10 lat, konsekwencją ucieczki było skazanie dożywotnie albo przeniesienie do pracy w kopalni (w formie opus metalli). W sytuacji, gdy sprawca został skazany na 10 lat i dopuścił się ucieczki na samym początku odbywania kary, powinno się rozważyć, czy jego kara powinna być podwojona, czy powinien być skazany dożywotnio, czy też przeniesiony do pracy w kopalni. Zdaniem jurysty w takiej sytuacji powinno się raczej wybierać między dwoma ostatnimi karami, gdyż jeśli podwojona kara przekraczałaby 10 lat, to nie powinno się wymierzać kary ograniczonej terminem.

${ }^{20}$ Digesta 48, 19,28, 14: Ita et in custodiis gradum servandum esse idem princeps rescripsit, id est ut, qui in tempus damnati erant, in perpetuum damnarentur, qui in perpetuum damnati erant, in metallum damnarentur, qui in metallum damnati id admiserint, summo supplicio adficerentur.

${ }^{21}$ Kara ta była wykonywana przez ukrzyżowanie, powieszenie, spalenie żywcem albo ścięcie. Zob. Digesta 48, 19,28pr.

${ }^{22}$ K. Amielańczyk, Rzymskie prawo karne..., s. 216-217.

${ }^{23}$ Digesta 48, 19, 8, 6: Inter eos autem, qui in metallum et eos, qui in opus metalli damnantur, differentia in vinculis tantum est, quod qui in metallum damnantur, gravioribus vinculis premuntur, qui in opus metalli, levioribus, quodque refugae ex opere metalli in metallum dantur, ex metallo gravius coercentur.

${ }^{24}$ Digesta 48, 19,8,7: Quisquis autem in opus publicum damnatus refugit, duplicato tempore damnari solet: sed duplicare eum id temporis oportet, quod ei cum superesset fugit, scilicet ne illud duplicetur, quo adprehensus in carcere fuit. et si in decem annos damnatus sit, aut perpetuari ei debet poena aut in opus metalli transmitti. plane si decennio damnatus fuit et initio statim fugit, videndum est, utrum duplicari ei tempora debeant, an vero perpetuari vel transferri in opus metalli: et magis est, ut transferatur aut perpetuetur. generaliter enim dicitur, quotiens decennium excessura est duplicatio, non esse tempore poenam artandam. 
Rzymskie prawo regulowało też odpowiedzialność penalną osób, które strzegły więźniów. W tytule trzecim księgi 48 Digestów zamieszczono relację Callistratusa ${ }^{25}$ zawierającą dwa reskrypty Hadriana, które dotyczą interesującego nas zagadnienia. Zgodnie z pierwszym reskryptem jeśli żołnierze pozwolili uciec aresztantom, których pilnowali, to oni ponosili odpowiedzialność. W razie ucieczki powinno się wszcząć postępowanie i ustalić, czy nastąpiła ona wskutek rażącego niedbalstwa strażników, czy przez przypadek, a także czy uciekła jedna osoba, czy więcej. Dla strażników, których wina była „nadmierna”, przewidziana była kara śmierci; w każdym innym przypadku kara powinna być wymierzona stosownie do stopnia winy (pro modo culpae). Na wymiar kary miała też z pewnością wpływ liczba uciekinierów. Z drugiego reskryptu wynika, że kara śmierci powinna być nałożona na strażnika, który uwolnił aresztanta albo świadomie trzymał go w taki sposób, aby mógł sam uciec (tak więc należy rozumieć nadmierną winę). Jeśli jednak strażnik dopuścił do ucieczki z powodu swojego pijaństwa ${ }^{26}$ lub lenistwa (opieszałości), powinien być ukarany chłostą i przeniesiony do gorszej służby ${ }^{27}$. Wolny od odpowiedzialności był strażnik, który utracił więźnia przez „,czysty przypadek" (vero fortuito). Zdaniem Callistratusa jeśli więzień uciekł z rąk strażników cywilnych powinno się przeprowadzić takie samo postępowanie, jak w stosunku do żołnierzy ${ }^{28}$. Omawianego zagadnienia dotyczy również wypowiedź Modestyna ${ }^{29}$,

${ }^{25}$ Digesta 48,3,12pr.: Milites si amiserint custodias, ipsi in periculum deducuntur. nam divus Hadrianus Statilio Secundo legato rescripsit, quotiens custodia militibus evaserit, exquiri oportere, utrum nimia neglegentia militum evaserit an casu, et utrum unus ex pluribus an una plures, et ita demum adficiendos supplicio milites, quibus custodiae evaserint, si culpa eorum nimia deprehendatur: alioquin pro modo culpae in eos statuendum. Salvio quoque legato Aquitaniae idem princeps rescripsit in eum, qui custodiam dimisit aut ita sciens habuit, ut possit custodia evadere, animadvertendum: si tamen per vinum aut desidiam custodis id evenerit, castigandum eum et in deteriorem militiam dari: si vero fortuito amiserit, nihil in eum statuendum.

${ }^{26}$ Termin per vinum należy rozumieć jako odurzenie alkoholem, a nie pijaństwo w sensie nałogu. Zob. A. Berger, Encyclopedic Dictionary..., s. 767.

${ }^{27}$ Zdaniem O.F. Robinson pijaństwo w tym przypadku mogło stanowić podstawę do prośby o złagodzenie kary (eadem, The Criminal Law..., s. 21). Słusznie stanowisko to skrytykował K. Amielańczyk, wskazując, że od Hadriana nieumyślne dopuszczenie do uwolnienia więźniów stało się samodzielnym typem przestępstwa (idem, Rzymskie prawo karne..., s. 224). Pijaństwo zostało zrównane przez Hadriana z przestępstwami nieumyślnymi popełnionymi na skutek niedbalstwa (P. Kubiak, Stan nietrzé́wości jako „,afekt” w rzymskim prawie karnym?, „Zeszyty Prawnicze" 2015, nr 1, s. 35). Popełnienie przestępstwa per vinum było kategorią pośrednią między dolus (umyślnością) a casus (przypadkiem) (A. Berger, Encyclopedic Dictionary..., s. 494).

${ }_{28}$ Digesta 48,3,12,1: Si paganos evaserit custodia, idem puto exquirendum, quod circa militum personas explorandum rettuli.

${ }_{29}$ Digesta 48,3,14,2: Qui si neglegentia amiserint, pro modo culpae vel castigantur vel militiam mutant: quod si levis persona custodiae fuit, castigati restituuntur. nam si miseratione custodiam quis dimiserit, militiam mutat: fraudulenter autem si fuerit versatus in dimittenda custodia, vel capite punitur vel in extremum gradum militiae datur. interdum venia datur: nam cum custodia cum altero custode simul fugisset, alteri venia data est. 
który stwierdził, że jeśli strażnik utracił aresztanta przez niedbalstwo, powinien być ukarany stosownie do stopnia winy (pro modo culpae) chłostą albo przeniesiony do gorszego rodzaju służby. W sytuacji, gdy znaczenie więźnia nie było duże (levis persona), strażnik po wychłostaniu mógł być przywrócony do poprzedniej służby. Jeśli jednak strażnik dopuścił do ucieczki więźnia oszukańczo (podstępnie, celowo), podlegał karze śmierci albo degradacji do najniższego stopnia wojskowego. Łagodniej traktowany był strażnik, który wypuścił więźnia z litości. Konsekwencją jego czynu było przeniesienie do innej służby wojskowej. Pozytywnie oceniana motywacja sprawcy była więc okolicznością łagodzącą. Strażnik odpowiedzialny za więźnia mógł być ułaskawiony, jeśli aresztant zbiegł z innym strażnikiem ${ }^{30}$. $\mathrm{Z}$ innej relacji Modestyna ${ }^{31}$ wynika, że pilnowanie aresztanta nie powinno być powierzane rekrutowi (niedoświadczonemu żołnierzowi - tiro). Jeśli więźniowi udało się uciec z powodu braku doświadczenia strażnika, odpowiedzialność za jego utratę ponosiła osoba, która powierzyła strażnikowi pilnowanie aresztanta. Mamy więc tutaj do czynienia z odpowiedzialnością zwierzchnika na zasadzie culpa in eligendo ${ }^{32}$. Należy dodać, że kara śmierci była przewidziana również dla strażnika-żołnierza, który wypuścił więźnia w zamian za łapówkę ${ }^{33}$. Śmiercią karany był także ten, kto uwolnił siłą (używając przemocy) więźnia pilnowanego przez żołnierza ${ }^{34}$. Modestyn opisał również zwyczaj, zgodnie z którym strażnikowi, który ponosi winę za ucieczkę więźnia, jeśli schwytanie tego więźnia jest ważne i zostanie to wykazane, powinno się dać czas na poszukiwanie zbiega i przydzielić mu do pomocy innego żołnierza ${ }^{35}$. Wydaje się, że gdyby strażnik zdołał złapać uciekiniera, nie ponosiłby odpowiedzialności ${ }^{36}$. Jeśli strażnik pilnował zbiegłego niewolnika, który powinien być zwrócony swojemu panu, i dopuścił do jego uciecz-

${ }^{30}$ P. Kołodko (Chłosta..., s. 70) przypuszcza, że w przypadku niezastosowania przebaczenia stosowano w takim przypadku chłostę jako typową karę dyscyplinarną. Warto nadmienić, że zgodnie z przekazem Modestyna aresztant powinien być zawsze pilnowany nie przez jednego strażnika, ale przez dwóch. Zob. Digesta 48,3,14,1. Należy sądzić, że chodziło o co najmniej dwóch strażników.

${ }^{31}$ Digesta 48,3,14pr.: Non est facile tironi custodia credenda: nam ea prodita is culpae reus est, qui eam ei commisit.

${ }^{32}$ Jak wskazuje G. Kuleczka, jest to odpowiedzialność karna za cudze działanie w przypadku lekkomyślności w dokonaniu wyboru osoby działającej. Zob. G. Kuleczka, Studia nad rzymskim wojskowym prawem karnym, Poznań 1974, s. 91.

${ }_{33}$ Sentencje Paulusa 5,31, 1: Si pecunia accepta miles custodiam dimiserit, capite puniendus est.

${ }^{34}$ Sentencje Paulusa 5,31,2: Qui custodiam militi prosequenti magna manu excusserunt capite puniuntur.

${ }^{35}$ Digesta 48, 3, 14, 6: Solet praeterea amissa culpa custodia, si tamen intersit eam adprehendi, tempus causa cognita militi dari ad eam requirendam, applicito ei alio milite.

${ }^{36}$ P. Sáry, The Penal Liability of the Prison Guards in Classical Roman Law, „Acta Universitatis Brunensis. Iuridica" 2016, t. 550, s. 202. 
ki, powinien zapłacić właścicielowi niewolnika jego cenę $e^{37}$. Strażnik był wolny od kary, jeżeli zrekompensował stratę niewolnika ${ }^{38}$. Z przekazu Paulusa ${ }^{39}$ wiadomo, że karze podlegał urzędnik więzienny (carceri praepositus) ${ }^{40}$, który w zamian za łapówkę pozwolił trzymać aresztanta niezakutego w łańcuchy lub wnieść do aresztu broń bądź truciznę. Jeśli niewłaściwe trzymanie aresztanta albo wniesienie niebezpiecznych przedmiotów zdarzyło się bez wiedzy takiego urzędnika, powinien on z powodu swojego niedbalstwa stracić posadę. Wynika z tego, że w prawie rzymskim penalizowano czyny sprowadzające niebezpieczeństwo ucieczki, popełnione zarówno umyślnie, jak i nieumyślnie ${ }^{41}$. Trudno powiedzieć, jaka kara groziła za typ umyślny. Na pewno była to kara surowsza niż utrata posady. Bardzo prawdopodobne, że za takie zachowania wymierzano czasem karę śmierci, szczególnie gdy doszło do ucieczki więźnia, który nie był zakuty w łańcuchy lub wykorzystał broń albo truciznę wniesioną do aresztu. Należy również dodać, że odpowiadał karnie za zdradę stanu (crimen maiestatis) ten, kto pozwolił uciec z aresztu oskarżonemu o zdradę stanu, który przyznał się już do winy przed sądem ${ }^{42}$.

\section{PRAWO STAROŻYTNYCH ATEN}

W starożytnych Atenach, podobnie jak w Rzymie, pozbawienie wolności pełniło kilka funkcji. Przeważnie stanowiło formę aresztu tymczasowego stosowanego przed procesem (jeśli oskarżony nie miał lub nie mógł mieć poręczyciela) albo po wydaniu wyroku (wobec skazanych na karę śmierci albo grzywnę). Rzadziej

37 Digesta 48,3,14,7: Quod si fugitivum domino reddendum prodiderit, si facultates habeat, domino pretium reddere iuberi Saturninus probat.

${ }^{38}$ P. Sáry, The Penal Liability..., s. 203.

39 Digesta 48,3,8: Carceri praepositus si pretio corruptus sine vinculis agere custodiam vel ferrum venenumve in carcerem inferri passus est, officio iudicis puniendus est: si nescit, ob neglegentiam removendus est officio.

${ }_{40}$ Wydaje się, że chodziło tu o naczelnika aresztu, gdyż słowo praepositus oznaczało w prawie rzymskim zwierzchnika osób pracujących (służących) w określonej gałęzi administracji. Zob. A. Berger, Encyclopedic Dictionary..., s. 645.

${ }^{41}$ Obecnie polskie prawo nie zna nieumyślnego typu uwolnienia lub ułatwienia ucieczki. Część przypadków, o których mowa wyżej, można by jednak kwalifikować z art. 231 § 3 k.k. Warto przy tym zauważyć, że kodeks karny z 1932 r. przewidywał karę za nieumyślne uwolnienie osoby prawnie pozbawionej wolności lub ułatwienie jej ucieczki (art. $151 \S 2$ ).

${ }^{42}$ Digesta 48, 4, 4pr.: Cuiusque dolo malo iureiurando quis adactus est, quo adversus rem publicam faciat [...] item qui confessum in iudicio reum et propter hoc in vincula coniectum emiserit. W okresie Republiki za zdradę stanu przewidziana była kara śmierci; w okresie Pryncypatu zaś stosowano przeważnie karę śmierci połączoną z konfiskatą mienia. Zob. O.F. Robinson, The Criminal Law..., s. 78. W odniesieniu do honestiores (ludzi o szlachetnym urodzeniu) zamiast kary śmierci orzekano często wygnanie. Zob. M. Melounová, Severitas and clementia in punishing the crimen maiestatis from Principate to Dominate, „Graeco-Latina Brunensia” 2013, t. 18, nr 1, s. 156. 
pozbawienie wolności stanowiło karę per se. Więziono również za długi wobec państwa ${ }^{43}$. Źródłami, z których możemy czerpać wiedzę o ateńskich rozwiązaniach prawnych dotyczących ucieczki więźnia, są dzieło Platona pt. Kriton oraz mowy sądowe wybitnego oratora Demostenesa.

Platon w Kritonie przedstawia rozmowę tytułowego bohatera z jego przyjacie-

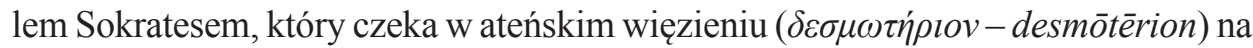
wykonanie wyroku śmierci wydanego na niego za bezbożność i psucie młodzieży. Kriton namawia Sokratesa do ucieczki, ten jednak stanowczo odmawia, argumentując to tym, że ucieczka byłaby czynem niesprawiedliwym, aktem nieposłuszeństwa wobec prawa. Na podstawie tego dialogu można ustalić, jakie konsekwencje były przewidziane przez ateńskie prawo w przypadku ucieczki osoby pozbawionej wolności. Pomoc w ucieczce, względnie uwolnienie uwięzionego, sprowadzało na sprawcę wypędzenie, utratę obywatelstwa i konfiskatę majątku; możliwa też była łagodniejsza kara, tj. konfiskata majątku połączona $\mathrm{z}$ obowiązkiem zapłaty określonej sumy pieniężnej ${ }^{44}$. Inne źródło - mowa Demostenesa przeciwko Timokratesowi - daje nam podstawę do stwierdzenia, że uwolnienie więźniów (przez otwarcie więzienia) mogło być karane śmiercią ${ }^{45}$.

Trudno ustalić, jakie konsekwencje ucieczki były przewidziane dla samego zbiega. Jeśli uszedł on do innego miasta, skazywał się na wygnanie i niesła-

${ }^{43}$ D.P. Phillips, The Law of Ancient Athens, Ann Arbor 2013, s. 42; V. Hunter, The Prison of Athens: A Comparative Perspective, „Phoenix” 1997, t. 51, nr 3-4, s. 300-307. Na temat penalnego pozbawienia wolności w Atenach zob. D. Allen, Imprisonment in Classical Athens, „The Classical Quarterly" 1997, t. 47, nr 1, s. 121-135.

${ }^{44}$ Dzieła Platona. 1. Apologia czyli Obrona Sokratesa, 2. Kriton, 3. Phedon czyli o nieśmiertelności duszy, thum. F. Kozłowski, Warszawa 1845, s. 230 i 245. Wypowiedź Kritona: „Ale odpowiedz na to Sokratesie: czy się obawiasz o mnie i innych przyjaciół, żebyśmy gdy stąd ujdziesz, nie byli od delatorów oskarżeni, żeśmy cię uprowadzili, i nie zmuszeni za to zostali utracić nasz majątek, zapłacić wiele pieniędzy, albo nawet narazić się na coś większego? Jeśli się o to lękasz, bądź spokojny. Myśmy nie tylko na to, ale nawet na większe powinni narazić się niebezpieczeństwa, skoroby tylko dla twego ocalenia tego było potrzeba. Słuchaj mnie i nie sprzeciwiaj się Sokratesie!" (ibidem, s. 230). Wypowiedź Praw ateńskich cytowana przez Sokratesa: „A teraz chcesz być nie stałym w tem do czegoś sam się zobowiązał! Sokratesie! dasz dowód twej stałości jeśli nas posłuchasz. Nie wystawisz się na śmiech wszystkich, jeśli w mieście pozostaniesz. Przeciwnie uważ co dobrego zrobisz dla siebie i twoich przyjaciół, jeśli staniesz się nam nieposłuszny, i coś zamierzył wykonasz! Przyjaciele twoi będą wypędzeni, utracą obywatelstwo, i pozbawieni zostaną majątku [...]" (ibidem, s. 244-245). Ciekawe jest, że Kriton mówi do przyjaciela: „Nie obawiaj się! bo nie wiele żądają za wybawienie i uprowadzenie cię stąd. Widzisz jak łatwo tych delatorów można przekupić, że nie wiele trzeba dla nich pieniędzy, a mój majątek cały jest gotów dla ciebie, i sądzę że wystarczy" (ibidem, s. 230). Oznacza to, że albo kara za pomoc w uwolnieniu więźnia nie była zbyt dotkliwa, albo że pomagające w ucieczce osoby i donosiciele byli tak chciwi, że ważniejsze były dla nich pieniądze, nawet niewielkie, niż możliwe konsekwencje ich uczynku. Biorąc pod uwagę to, co zostało napisane, wydaje się, że druga możliwość jest bardziej prawdopodobna.

${ }^{45}$ The Orations of Demosthenes, thum. C.R. Kennedy, t. IV, London 1861, s. 52. 
$w_{e ̨}{ }^{46}$. Interesujące jest, że ucieczka do innego miasta podczas procesu, zanim jeszcze wydano orzeczenie, nie była tak haniebna ${ }^{47}$. Z pierwszej mowy Demostenesa przeciwko Aristogitonowi można się dowiedzieć, że uciekinier był ścigany przez zarządców ateńskiego więzienia, zwanych ,Jedenastu” ${ }^{48}$. Nie wiadomo jednak, co stałoby się ze zbiegiem, gdyby został złapany.

\section{PODSUMOWANIE}

Należy zauważyć, że ucieczka więźnia w starożytnym Rzymie i Atenach pociągała konsekwencje zarówno dla osoby uciekającej, jak i osób, które uwolniły więźnia bądź ułatwiły mu ucieczkę. Odpowiedzialność tych osób miała charakter penalny w tym sensie, że pociągała za sobą karę. Na ile tę karę można nazwać kryminalną, a na ile dyscyplinarną w dzisiejszym rozumieniu tych słów, trudno powiedzieć. Jak już wskazałem na początku, nie wydaje się konieczne, a nawet możliwe nakładanie na rozwiązania antyczne ram pojęć funkcjonujących w dzisiejszej nauce prawa karnego. Istotne jest stwierdzenie, że omawiane zachowania spotykały się z reakcją, często bardzo surową (kara śmierci). Biorąc pod uwagę okres, w jakim powstawało prawo rzymskie (starożytność), podziw mogą budzić

${ }^{46}$ Dzieła Platona..., s. 245. Ciąg dalszy wypowiedzi ateńskich Praw: „Sam jeśli się udasz do którego z najbliższych miast, do Teb, do Megary (bo tam najlepsze są prawa), będziesz miany za nieprzyjaciela rządu. Każdy dobry obywatel będzie spoglądał na ciebie z nieufnością, jako na gwałciciela praw. Utwierdzisz mniemanie sędziów, że sprawiedliwie cię potępili: bo przestępca praw byłby zgorszeniem dla młodych osobliwie i lekkomyślnych ludzi. Może więc nie pójdziesz do tych miast, gdzie są dobre prawa i żyją cnotliwi ludzie. Ale czy warto będzie dla ciebie wtenczas żyć? Jeśli zaś pójdziesz, cóż powiesz Sokratesie? Czy się nie powstydzisz tego coś tu mawiał: że nic droższego dla każdego obywatela być nie powinno nad cnotę, sprawiedliwość, prawa, i ich powagę? Czy sądzisz że twoje teraz postępowanie, sprzeczne z tem coś dawniej mówił, nie będzie źle tam uważane? Nie sądź tego Sokratesie! Porzucisz zatem miasta gdzie rząd dobry panuje, a przeniesiesz się do Thessalii, do przyjaciół Kritona: bo tam jest największy nieład i wolność bez granic. Będą cię słuchać z ochotą gdy będziesz opowiadał, jak dziwnym sposobem uszedłeś z więzienia okryty płaszczem, lub skórą zwierza, lub przebrany, jak zwykle robią zbiegowie aby ich nie poznano! Ale któż z nich nie zadziwi się, że starzec któremu mało dni do zgonu pozostaje, znieważywszy prawa, i wszystko co jest najświętsze, żyć jeszcze pragnie? Nikt! Może odpowiesz - jeśli nikogo nie obrażę. Lecz jeśli przypadkiem to zrobisz, usłyszysz wtenczas wiele wyrzutów, które ci wcale nie przystoją! Będziesz zatem żył dla wszystkich uniżony, przed wszystkiemi się czołgając!” (ibidem).

47 Oddajmy znów głos Prawom: „Gdybyś był chciał mógłbyś był w czasie samej sprawy obrać sobie wygnanie: i co teraz przeciw woli Rzeczypospolitej zamyślasz, wtenczas z jej zgodą zrobić. Lecz ty wówczas odzywałeś się z uniesieniem niby wzniosłem, że cię mało obchodzi, iż musisz umrzeć; oświadczałeś że wolisz śmierć nad wygnanie; a teraz nie wstydzisz się zdań swoich, i nie rumienisz się że chcesz gwałcić prawa? Odważasz się na to, na co by zaledwie najpodlejszy niewolnik się odważył! Usiłujesz uciec! mimo oświadczeń i zobowiązań się przez jakie nam się poddałeś [...]" (ibidem, s. 243-244).

${ }^{48}$ The orations of Demosthenes..., s. 71. 
przyjęte w nim rozwiązania. Przyzwyczailiśmy się do myśli, że to rzymskie prawo prywatne stało na bardzo wysokim poziomie, natomiast system prawa karnego nie był tak doskonały. Należy jednak zauważyć, że mimo wielu źródeł odnoszących się do kwestii ucieczek więźniów nie było w nich sprzeczności. Ponadto duży nacisk kładziono na subiektywizację odpowiedzialności - rozróżniano przestępstwa popełnione umyślnie i nieumyślnie, uzależniano wysokość kary od stopnia winy, wyłączano odpowiedzialność za przypadek. Jeśli zaś chodzi o prawo starożytnych Aten, to wzmiankę o nim traktuję jako inspirację dla badaczy historii prawa do zgłębienia tej problematyki.

\title{
PENAL RESPONSIBILITY \\ FOR THE ESCAPE OF A PERSON WHO WAS LEGALLY DEPRIVED OF LIBERTY UNDER ROMAN LAW AND LAW OF ANCIENT ATHENS
}

\begin{abstract}
The subject matter of the present article is the issue of penal responsibility as a consequence of an escape by a person who was legally deprived of their liberty in connection with a committed offence (or due to be charged with committing an offence) under Roman law and under the law of Ancient Athens. The paper focuses on describing the responsibility of the person who escaped (from the place where they were confined to in connection with the execution of a preventive measure or from where they were imprisoned) as well as of persons who contributed (intentionally or unintentionally) to such an escape.
\end{abstract}

Keyw ords: escape of a person legally deprived of liberty, roman criminal law, criminal law of Ancient Athens 